\title{
COMPOSITION AND THE REDOX STATE OF THE SLAVE PERIDOTITIC MANTLE
}

\author{
Maya Kopylova and Catherine McCammon ${ }^{1}$ \\ The University of British Columbia, Canada $;^{\prime}$ - Universität Bayreuth, Germany.
}

\section{INTRODUCTION}

The Slave craton has now been studied with sufficient thoroughness to recognize the blocky, quilt-like structure of its underlying mantle. Three compositionally-distinct, northeast-trending lithospheric domains have been defined (Grütter et al., 1999); the southern terrane is divided further along the "Pb line" (Thorpe et al., 1992) into western and eastern parts with contrasting compositions (Carbno and Canil, 2002). The tentative NW-SE divisions between mantle domains identified by geochemical mapping with heavy minerals in exploration samples and kimberlites cut through the mainly N-S crustal divisions of the craton. Our study characterizes and compares the peridotitic upper mantle below distinct terranes of the Slave craton and determines common and atypical petrological features of the craton in the worldwide context. The comparison is based on our original data on the northern (N) and southeastern (SE) Slave and on available literature data on the central (C, Pearson et al., 1999; Griffin et al., 1999a, b) and southwestern (SW, Carbno and Canil, 2002) Slave craton.

\section{MATERIALS AND METHODS}

We studied two suites of mantle xenoliths brought up by the N Slave Jurassic Jericho kimberlite and by the SE Slave Cambrian Gahcho Kue kimberlite. The suites include several types of peridotites, pyroxenites and eclogites. This paper focuses on peridotitic xenoliths; they are present in garnet, spinel or spinel-garnet $(\mathrm{N}$ Slave only) facies and have coarse or deformed texture. Detailed examination of mineral composition and thermobarometric methods were used to constrain the ambient thermal regime of the mantle at the time of the kimberlite eruption (Kopylova et al., 1999; Kopylova and Caro, 2001). Larger and fresher samples were analysed for major element bulk compositions. Modal mineral abundances were estimated by three methods: a computer-assisted image analysis, point counting in thin sections, and conversion of bulk compositions into an equivalent modal mineralogy (Kopylova and Russell, 2000, Kopylova and Caro, 2001). The oxygen barometry was based on $\mathrm{Fe}^{3+} / \Sigma \mathrm{Fe}$ ratios measured on the Mössbauer milliprobe (McCammon et al., 1991) in hand picked grains of spinel and garnet.

\section{THERMAL STATE AND BULK COMPOSITION OF THE SLAVE PERIDOTITIC MANTLE}

Peridotitic mantle of the Slave craton contains forsterite, enstatite (mg-number 90-94), Cr-diopside, lherzolitic Ca-saturated garnet, and chromite (33-60 wt $\left.\% \mathrm{Cr}_{2} \mathrm{O}_{3}\right)$. Based on mineral chemistry and thermobaromety, the peridotite samples are assigned to a low-temperature (lithospheric) and a high-temperature (asthenospheric) suite. The low-temperature depleted peridotites are predominantly coarse in the $\mathrm{N}$ and $\mathrm{C}$ Slave, and have coarse or porphyroclastic textures in the SE Slave. They are equilibrated on a cold geotherm characteristic of Archean cratons. The high-temperature peridotite is found below the $\mathrm{N}$ and $\mathrm{C}$ Slave. The $\mathrm{N}$ Slave high-T samples show non-disrupted porphyroclastic textures and are shifted off the geotherm to higher temperatures. The SE Slave mantle is colder than the cratonic mantle of Kaapvaal, Siberia, Fennoscandia, Tanzania and Superior and other blocks of the North American craton (Fig. 1) and may be the coldest mantle terrane recognized so far.

The Slave peridotites contain $60-88$ vol \% olivine with mg-number $=0.895-0.935$. All terranes of the Slave mantle with available data (N, C and SE) show broadly similar compositions and are markedly distinct from low-T peridotites from the Kaapvaal and Siberian cratons. Olivine-poor, orthopyroxene-rich, low-T peridotite is absent on the Slave craton, and compositions of its olivine extend to less magnesian values. Spinel peridotites of the SE Slave plot within the corresponding field for the N Slave. Coarse, lowtemperature garnet peridotites of the N, C and SE Slave are also similar. Deformed peridotites of the SE Slave fit within the field for low-temperature Slave peridotites. A pyroxene/olivine ratio in peridotites can also be estimated through an elemental $\mathrm{Mg} / \mathrm{Si}$ ratio. The $\mathrm{Mg} / \mathrm{Si}$ value in the SE and N Slave peridotites ( $1.26-$ 1.34) is comparable to these ratios in the Siberian and Fennoscandian cratons. Extremes in the worldwide datasets are represented by the low- $\mathrm{T}$ garnet peridotites from the Kaapvaal $(\mathrm{Mg} / \mathrm{Si}=1.22$; Boyd, 1989) and the central Slave $(\mathrm{Mg} / \mathrm{Si}=1.37$; Griffin et al., 1999a), which have exceptionally low and high olivine modes, respectively. These data suggest that the Archean peridotitic mantle is not necessarily olivine-poor and an 


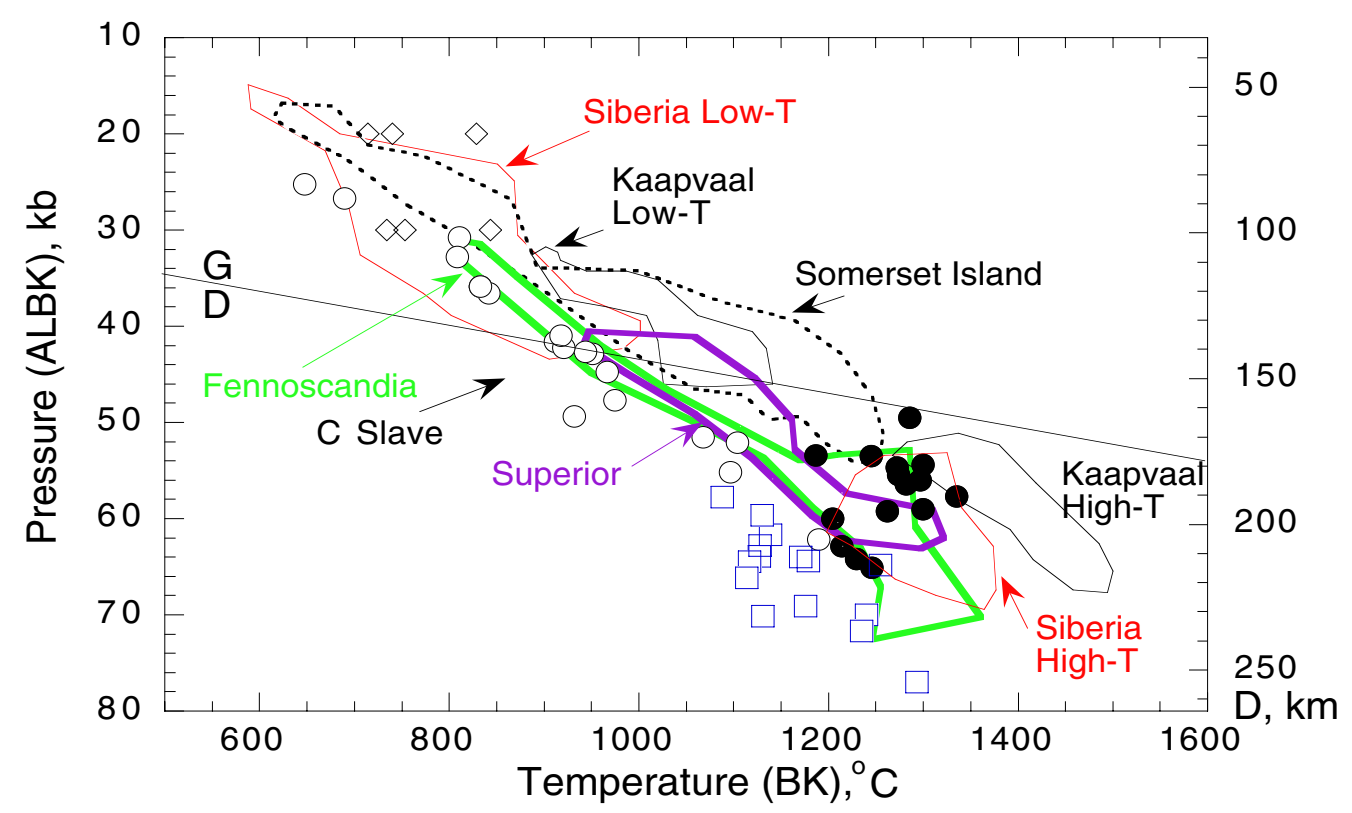

Fig. 1. Pressure (orthopyroxene-garnet barometer of Brey and Köhler, 1990) and temperature (two-pyroxene thermometer of Brey and Köhler, 1990) estimates for the cratonic mantle. Estimates for the SE and N Slave xenoliths are shown as diamonds (SE Slave spinel peridotite), squares (SE Slave garnet perridotite), open circles (N Slave low-T garnet peridotite) and filled circles (N Slave high-T garnet peridotite, pyroxenites and megacrysts). A P-T field for the C Slave (stippled pattern) is based on Lac de Gras data (Pearson et al., 1999), for the Kaapvaal craton on thermobarometry of the Kimberley and Lesotho xenoliths (Boyd, unpublished data), for the Siberian craton on the Udachnaya (Boyd et al., 1997) and Mir xenoliths (Roden et al., 1999), for the Fennoscandian craton on the Eastern Finland kimberlites (Kukkonen and Peltonen, 1999), for the Superior craton on the Kirkland Lake xenoliths (Meyer et al., 1994), for the northern Canadian Shield on the Somerset Island kimberlites (Kjarsgaard and Petersen, 1992; Schmidberger and Francis, 1999).
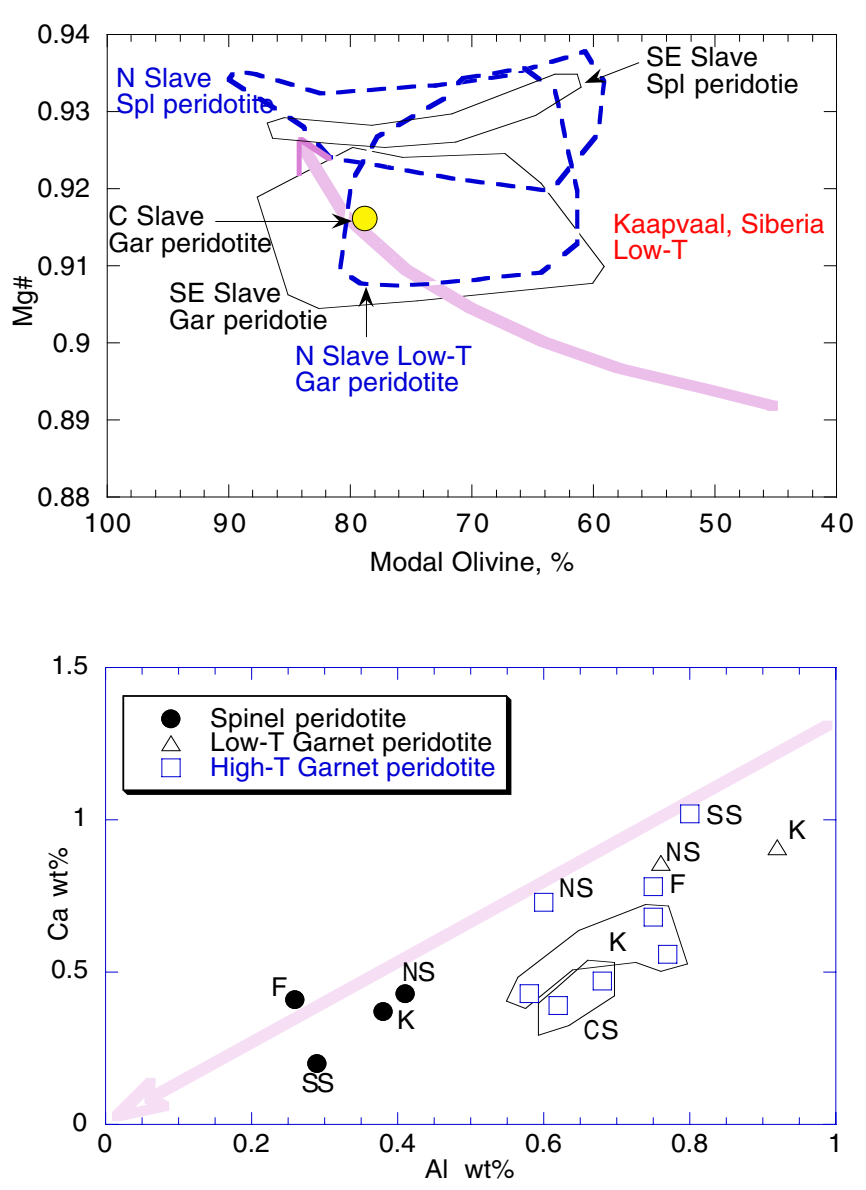

Fig. 2. Mg-number vs. modal olivine (vol \%) for the Slave peridotite. Mg-number is for olivine where mineral chemical compositions are available or else represents values of bulk whole rock composition. The latter are calculated assuming all iron as $\mathrm{FeO}$ and are generally equivalent to the mg-number of olivine in the same rock. Fields outline peridotite compositions of $\mathrm{N}$ Slave (thick dashed lines, Kopylova and Russell, 2000) and SE Slave peridotites (solid lines) and the Kaapvaal and Siberian peridotites (stippled pattern, Boyd, 1989, Boyd et al., 1997; Boyd et al., 1999). A circle indicates a median composition of the central Slave peridotite (Griffin et al., 1999b); an arrow designates the "oceanic trend" of Boyd (1989).

Fig. 3. The $\mathrm{Ca}(\mathrm{wt} \%)$ - $\mathrm{Al}$ (wt \%) compositions of cratonic peridotites. K- the Kaapvaal average and median low-T garnet lherzolite and harzburgite (Boyd, 1989; Griffin et al., 1999b), mean high-T peridotite and median spinel peridotite (Griffin et al., 1999b); F - the Fennoscandian averages for low-T spinel-garnet and garnet peridotite calculated from data of Peltonen et al., (1999); CS - the central Slave average (Griffin et al., 1999a) and median (Griffin et al., 1999b) for low-T garnet peridotite; NS - the N Slave average (Kopylova and Russell, 2000) for low-T spinel and garnet-bearing peridotite; SS - the SE Slave average for coarse spinel and garnet peridotite. Fields for the low-temperature garnet peridotites of the Kaapvaal and C Slave are outlined by a dashed line. An arrow delineates the overall trend expected for depletion of oceanic peridotite (Boyd, 1989). 
orthopyroxene enrichment seems to be most pronounced only on the Kaapvaal craton.

Greater depletion of shallow spinel peridotites below the SE and N Slave is suggested by their more Mg-rich olivine compositions (Fig. 2). An Al-Ca plot (Fig. 3) further supports this conclusion. The spinel peridotite compositions are extremely depleted and poor in $\mathrm{Ca}$ and $\mathrm{Al}$. In contrast, the garnet-bearing xenoliths contain more $\mathrm{Ca}$ and $\mathrm{Al}$ and plot towards a less depleted end along the trend produced by basalt extraction at low pressure. This pattern is noted for the Fennoscandian and Kaapvaal cratons, which suggests that greater depletion of the shallow peridotitic subcratonic mantle may be the rule rather than the exception.

A pronounced contrast in chemical compositions between the shallow and deeper lithosphere characterizes all Slave mantle terranes as summarized on Fig. 4. Everywhere the shallow mantle shows greater chemical depletion than its deeper portion, which is consistent with the density profile of a long-stabilized peridotite. It also suggests that the younger, less depleted mantle (Griffin et al., 1999b) always underlies older mantle blocks.

Below the SE Slave, the chemical contrast is manifested in lower $\mathrm{Fe}$ content and in significant depletion in $\mathrm{Al}$ and $\mathrm{Ca}$. This chemical change could be either gradual, over $50 \mathrm{~km}$, or sharp; an absence of samples from intermediate depths makes both of these models plausible. Below the N Slave, one of the major chemical boundaries occurs at a depth of $80-100 \mathrm{~km}$; it separates shallow, more Fe-depleted, garnet-free mantle from deeper garnet-bearing mantle (Kopylova and Russell, 2000). Analysis of Re-Os isotopic compositions and chondrite-normalized PGE patterns shows that the N Slave mantle is also stratified with respect to age. The spinel peridotite generally yields older Archean-Proterozoic $\mathrm{T}_{\mathrm{RD}}$ and $\mathrm{T}_{\mathrm{MA}}$ model ages (Irvine et al., 1999; Irvine, 2002). This stratification in ages reflects refertilization of the deeper mantle or an incremental downward growth of the mantle.

A two-layer lithospheric structure was also reported for the C Slave. The upper, ultra-depleted layer occurs down to depths of $150 \mathrm{~km}$ and $900^{\circ} \mathrm{C}$ and thins towards the north, south and southwest. The shallow layer may be formed at the active convergent margin at 2.6-2.7 $\mathrm{Ga}$, whereas the lower, 2.6 Ga layer may represents material that rose diapirically from the lower mantle (Griffin et al., 1999a).

A shallow, ultra-depleted layer of mantle lithosphere beneath the SW margin of the craton may be indicated by garnet compositions of the Dry Bones kimberlite. Garnets with high $\mathrm{Zr}(>40 \mathrm{ppm})$ are not found at temperatures $\mathrm{T}_{\mathrm{Ni}}$ below $900^{\circ} \mathrm{C}$ (Carbno and Canil, 2002). The correlation of geochemical parameters with temperatures estimated from $\mathrm{Ni}$ may reflect different degrees of reworking by a hot metasomatising front or a true chemical stratification. If the chemical changes in the SW Slave garnets do represent mantle stratification, the depleted shallow mantle may stretch all across the southern terrane. The difference between the SW and SE Slave terranes may relate only to the absence of the lithospheric keel at $160-250 \mathrm{kms}$ in the southwest; it is this basal part of the lithosphere that hosts high-Cr garnets in the eastern part of the southern Slave contains (Grutter et al., 1999a)

At present we do not know geometry of the chemically distinct layers and therefore cannot unequivocally interpret their origin. Seismic reflection studies detect dipping discontinuities in the uppermost cratonic mantle (Calvert et al., 1995) interpreted as buried subducted blocks. The chemical boundary in the SW Slave was explained as a trace of oblique underplating of subducted Proterozoic lithosphere (Carbno and Canil, 2002). If one accepts subduction as the principal process of the craton assembly, chemical discontinuities mapped in the Slave mantle, should be dipping towards the interior of the craton (Fig. 4) at every stage of the craton development. The present craton should have several nested sets of these steep joint surfaces that may be chemically and seismically expressed. However, the growth of craton through addition of sub-horizontal layers of underplating mantle material is equally feasible. These layers would be much less visible on seismic reflection traverses because they do not involve seismically contrasting eclogites (J. Percival, pers. comm.). The resulting mantle structure would be stratified (Kopylova and Caro, 2001).

The minimum lithospheric thickness of the Slave craton varies greatly between terranes, as indicated by different depths to high-T peridotites enriched by asthenospheric magmas (Fig. 4). The lithosphere of the SE Slave is at least $220-250 \mathrm{~km}$ deep and thicker than that of the N Slave $(160-190 \mathrm{~km})$, the C Slave $(200 \mathrm{~km})$ and the SW Slave (160-190 km). The thicker lithosphere and a colder thermal regime contribute to the higher diamond potential of the SE Slave.

\section{REDOX PROFILE OF THE SLAVE PERIDOTITIC MANTLE}

Oxygen barometry enabled us to constrain the redox profile of the Slave peridotitic mantle, which transects 3 depth facies of peridotites and layers of different bulk composition as well as the graphite and diamond stability fields (Fig. 5). The use of an internally 


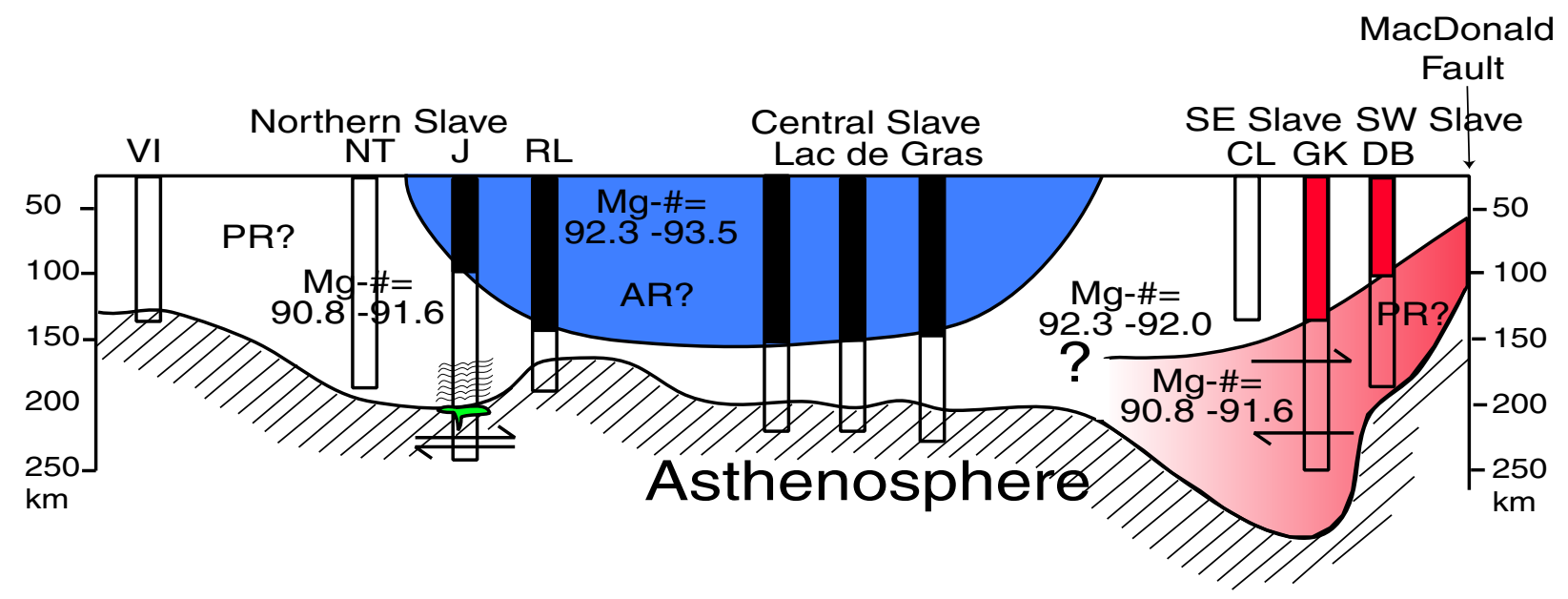

Fig. 4. A hypothetical deep structure of the Slave mantle in a N-SE-SW cross-section reconstructed on the premise that apparent differences between the Slave mantle terranes reflect the lateral heterogeneity of the craton rather than its temporal evolution. Vertical columns are mantle suites sampled by the Victoria Island (VI), Ranch Lake (RL), Lac de Gras, Camsell Lake kimberlites and northern tills (NT) (Griffin et al. , 1999a), as well as by the Dry Bones (Carbno and Canil, 2002), Jericho (J) and Gahcho Kue (GK) kimberlites. The stratigraphy of the Jericho and Gahcho Kue mantle samples is based on the BreyKöhler thermobarometry. Mg-numbers are ranges of olivine compositions observed in the Jericho and Gahcho Kue peridotite xenoliths from corresponding depths. Intrusions of magmatic pyroxenites (green) and an overlying layer of fertile peridotites are marked for the Jericho pipe. Arrows denote occurrences of deformed peridotites. See text for descriptions of chemically contrasting mantle peridotites in all terranes of the craton.

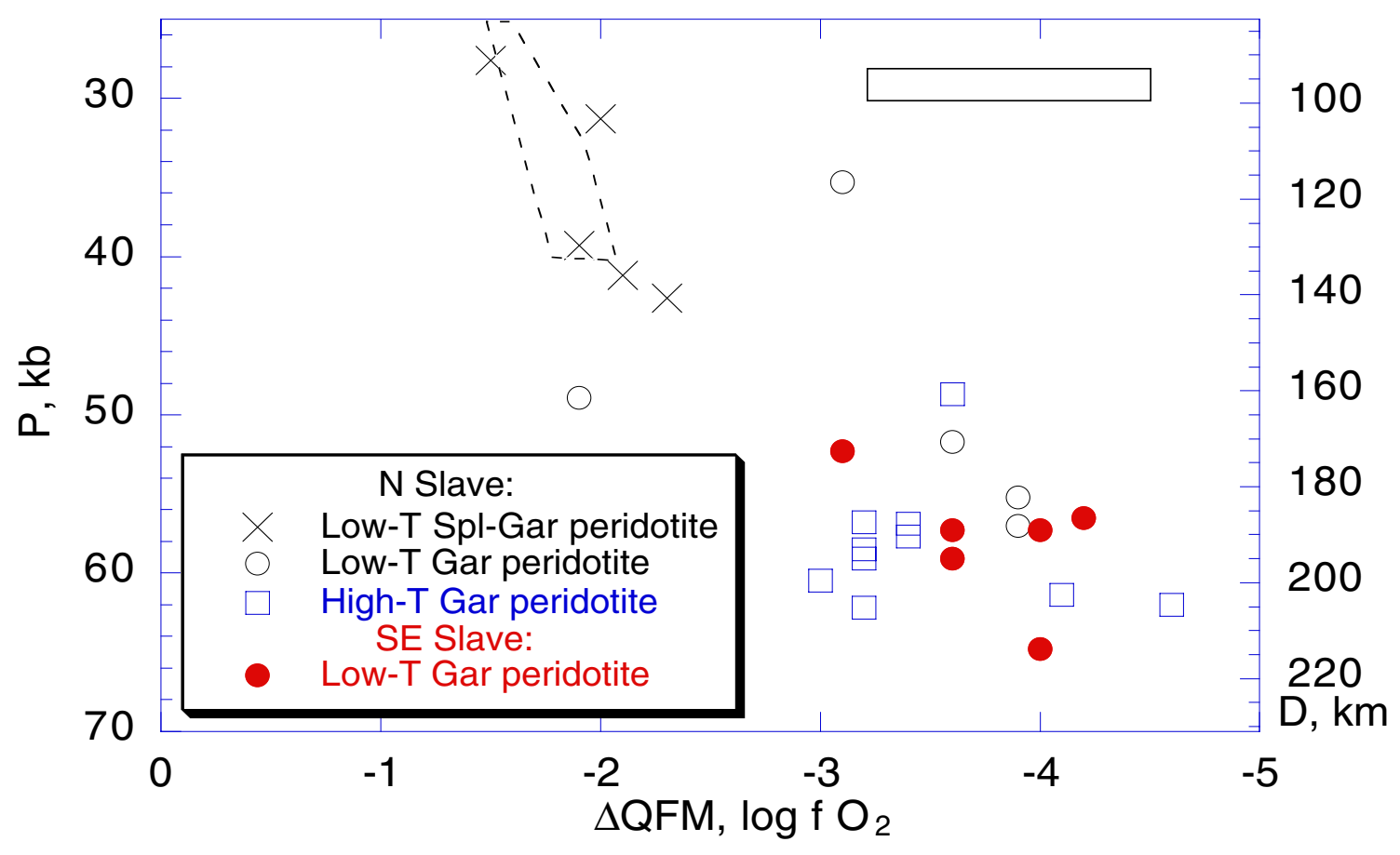

Fig. 5. Oxygen fugacity (relative to QFM) of Slave peridotites and pyroxenites as a function of depth. Oxygen fugacities are estimated according to the Gudmundsson and Wood (1995, GW) garnet-orthopyroxene-olivine oxygen barometer. A P-fO2 field for spinel peridotites (solid line) is calculated using the O'Neill and Wall (1987; OW) spinel-orthopyroxene-olivine oxygen barometer. A P-fO2 field for spinel-garnet peridotites (dashed line) outlines estimates of oxygen fugacity made by the OW barometer for two different thermobarometric solutions: 1) the OW temperatures projected onto the N Slave geotherm, and 2) the Finnerty-Boyd (1987) temperatures paired with the MacGregor (1974) pressures. Note that the GW estimates offO2 for thesesamples(crosses)plotvery close to the dashed field, attesting toconsistencybetweentheOl-Opx -Spl OW estimates and the Ol-Px-Gar GW estimates. 
consistent set of oxygen barometers and thermometers as well as petrological constraints ensures the consistency and accuracy of data at all mantle depths. Absolute oxygen fugacities of all layers in the Slave mantle increase with depth and plot roughly along the WM buffer. As expected from drastically different $\mathrm{Fe}^{3+} / \mathrm{Fe}_{\text {Total }}$ spinel ratios in spinel and spinel-garnet peridotites, the spinel peridotite equilibrated at a much lower $\mathrm{fO}_{2}(6 \mathrm{QFM}=-3.1--4.2 \log$ units $)$ than the spinel-garnet peridotite ( $6 \mathrm{QFM} \sim-2 \log$ units). Spinelfree garnet peridotite shows a relative reduction with $170-210 \mathrm{~km}$ depth from $(6 \mathrm{QFM})=-3$ to $-4.5 \log$ units $\mathrm{fO}_{2}$.

The redox state of spinel-free coarse and deformed peridotite of SE Slave is identical to that of the N Slave. Even though the SE Slave peridotites are equilibrated at a lower geotherm, they are not appreciably more reduced. The low- $\mathrm{T}$ and high-T peridotites of the $\mathrm{N}$ Slave have an identical redox state and do not support the generalization of an oxidizing asthenosphere underlying a reduced lithosphere.

The Slave data show that where two types of peridotites coexist at a given depth, they have different redox states (Fig. 5). Oxygen fugacity shifts suddenly at the boundary between layers with different oxide mineralogies, and change gradually in the mineralogically homogeneous layers in response to increasing $\mathrm{P}$ and $\mathrm{T}$. This is the pattern expected of $\mathrm{fO}_{2}$ if oxygen is intrinsically controlled by $\mathrm{Fe}$ equilibria. Another consequence of an Fe-buffered mantle would be a correlation between redox state and chemical depletion of the mantle. $\mathrm{Fe}^{3+}$ is extracted by melt since it is highly incompatible; hence melting should produce reduced residues and oxidized magmas. This correlation is indeed observed in the N Slave mantle. Depleted spinel peridotites of the $\mathrm{N}$ Slave show significantly lower $\mathrm{Fe}_{2} \mathrm{O}_{3}$ in bulk rock and $\mathrm{Fe}^{3+}$ content in spinel. A stronger depletion of the spinel peridotites is consistent with more intense melt extraction in the early history of the Earth. Lower oxygen fugacities of depleted rocks could explain an observed strong preference of elemental carbon for cratonic harzburgites and eclogitic residues produced by extraction of silicic trondjemite-tonalite-granodioritic magmas.

\section{REFERENCES}

Boyd, F.R., Pokhilenko, N. P., Pearson D. G., Mertzman S. A., Sobolev N. V. \& Finger L.W. Contrib. Miner. Petrology. 128, 228-246, (1997).

Boyd, F.R. Earth and Planetary Science Letters, 96,15-26, (1989)

Boyd, F. R., Pearson, D. G. \& Mertzman, S. A. In:. Proc. 7th Int. Kimberlite Conference (ed. Gurney, J.J. \&
Richardson, S.R.), Red Roof Designs, Cape Town, 40-47, (1999).

Brey, G.P. \& Köhler, T., J. of Petrology, 31, 1353-1378, (1990).

Calvert, A.J., Sawer, E.W., Davis, W.J., \& Ludden, J.N. Nature, 375, 670-674, (1995)

Carbno, G. B. \& Canil, D., J. of Petrology, 43, 1, 129-142, (2002).

Finnerty, A. A. \& Boyd, F.R. In: Mantle Xenoliths (ed. Nixon, P.H.), New York: John Wiley, 381-402, (1987).

Griffin, W. L., Doyle, B.J., Ryan, C. G., Pearson, N. J., O’Reilly, S. Y., Davies, R., Kivi, K., van Achterbergh, E. \& Natapov, L.M. , J. of Petrology , 40, 5, 705-727, (1999a).

Griffin, W.L., O’Reilly, S. Y., \& Ryan, C. G. Geochemical Society, Special Publication No. 6, 13-45, (1999b).

Grütter, H. S., Apter D. B. \& Kong, J. In:. Proc. 7th Int. Kimberlite Conference (ed. Gurney, J.J. \& Richardson, S.R.), Red Roof Designs, Cape Town, 307-312, (1999).

Gudmundsson, G., \& Wood, B.J. Contrib. Miner. Petrology, 119, 56-67, (1995).

Irvine, G., Kopylova, M. G., Carlson, R. W., Pearson, D. G., Shirey, S. B. \& Kjarsgaard B. A., 9th V.M. Goldschmidt Conference, Lunar and Planetary Institute, Houston, 134135, (1999).

Irvine, G.J., PhD Thesis, University of Durham (2002).

Kjarsgaard, B. A. \& Petersen, T.D. Current Research, Part B; GSC, Paper 92-1B, 1-6, (1992).

Kopylova, M. G., Russell J. K. \& Cookenboo, H. J. of Petrology , 40, 1, 79-104, (1999)

Kopylova, M. G. \& Russell, J. K., Earth Planet. Sci. Lett. ,181, 71-87, (2000).

Kopylova, M.G., \& Caro, G., In: The Slave-Kaapvaal workshop. 5-9 Sept., 2001.

Kukkonen, I. T., \& Peltonen, P. Tectonophysics, 304 301315, (1999).

MacGregor, I. D. American Mineralogist 59, 110-119, (1974).

McCammon, C.A., Chaskar V., \& Richards, G.G., Meas. Sci. Technol., 2, 657-662, (1991).

McCammon, C. A., Griffin, W. L.,.Shee, S.R, \& O’Neill, H.St. C., Contrib. Miner. Petrology, 141, 287- 296, (2001).

Meyer H.O.A., Waldman M.A., \& Garwood B.L. Canadian Mineralogist, 32, 295-306, (1994)

O’Neill, H. St. C. \& Wall, V .J. J. of Petrology 28, 6, 1169 1191, (1987).

Pearson, N. J., Griffin, W. L., Doyle, B. J, O’Reilly, S. Y., van Achtenbergh, E. \& Kivi, K. In:. Proc. 7th Int. Kimberlite Conference (ed. Gurney, J.J. \& Richardson, S.R.), Red Roof Designs, Cape Town, 644-658, (1999).

Roden, M.F., Laz'ko, E.E., \& Jagoutz, E. In:. Proc. 7th Int. Kimberlite Conference (ed. Gurney, J.J. \& Richardson, S.R.), Red Roof Designs, Cape Town, 664-676, (1999).

Schmidberger, S. S., \& Francis, D. Lithos , 48, 195-216, (1999).

Thorpe, R.I., Cumming, G.L., \& Mortensen, J.K., In: Canada-NWT MDA summary volume, Geological Survey of Canada, Open File 2484, 179-184, (1992).

Contact: MG Kopylova, EOS Dept, the University of British Columbia, 6339 Stores Rd, BC, Canada, V6T 1Z4, E-mail: mkopylov@eos.ubc.ca 